\title{
Hyperferritinemia and COVID-19?
}

\author{
Ivana Čepelak ${ }^{1}$, Slavica Dodig ${ }^{1}$, Ivana Vučenik ${ }^{2}$ \\ ${ }^{1}$ University of Zagreb Faculty of Pharmacy and Biochemistry, Department of Medical Biochemistry and Haematology, Zagreb, \\ Croatia \\ ${ }^{2}$ University of Maryland School of Medicine, Department of Medical and Research Technology, Baltimore, Maryland 21201, \\ USA
}

OPEN ACCESS

\section{Correspondence:}

Ivana Čepelak ivcepelak@gmail.com orcid.org/0000-0001-7934-599X

This article was submitted to RAD CASA - Medical Sciences as the original article

Conflict of Interest Statement: The authors declare that the research was conducted in the absence of any commercial or financial relationships that could be construed as a potential conflict of interest.

Received: 27 October 2020 Accepted: 17 November 2020 Published: 28 December 2020

Citation:

Čepelak I, Dodig S, Vučenik I. Hyperferritinemia and COVID-19? RAD CASA - Medical Sciences. $544=52-53$ (2020): 18-25 DOI: https://dx.doi.org/10.21857/ ygjwrcdv0y

Copyright (C) 2020 Čepelak I, Dodig $\mathrm{S}$, Vučenik I. This is an open-access article distributed under the terms of the Creative Commons Attribution License (CC BY). The use, distribution or reproduction in other forums is peror reproduction in other forums is per-
mitted, provided the original author(s) and the copyright owners(s) are credited and that the original publication in this journal is cited, in accordance whit accepted adacemic practice. No

use, distribution or reproduction is permitted which does not comply with

\section{ABSTRACT:}

It has been repeatedly described that increased serum ferritin concentration or hyperferritinemia is associated with COVID-19, especially with more severe forms of this disease.

Ferritin is a molecule whose concentration is determined as a marker of reflecting the body's iron supply and less significantly as a marker of inflammation of infectious and non-infectious origin. The expression of this vital molecule for iron metabolism is therefore regulated, primarily by an irondependent mechanism. However, in addition to this regulation, there appears to be feedback between ferritin and cytokines in the control of pro-inflammatory and anti-inflammatory mediators.

This review paper includes basic data on ferritin and the potential causes and consequences of hyperferritinemia with implications for COVID-19.

KEYWORDS: hyperferritinemia; COVID-19; inflammation; iron metabolism; ferritin

\section{SAŽETAK}

Hiperferitinemija I COVID-I9?

Poznato je da je povećana koncentracija feritina u serumu ili hiperferitinemija povezana s COVID-19, posebno u težim oblicima ove bolesti.

Feritin je molekula čija se koncentracija određuje kao biljeg koji odražava opskrbu organizma sa željezom, te manje značajno kao biljeg upale infektivnog i neinfektivnog podrijetla. Ekspresija ove molekule neophodne za metabolizam željeza stoga je regulirana, prvenstveno mehanizmom koji ovisi o željezu. Međutim, pored ove regulacije, čini se da postoje i povratne informacije između feritina i citokina u kontroli proupalnih i protuupalnih medijatora.

Ovaj pregledni članak uključuje osnovne podatke o feritinu i potencijalnim uzrocima i posljedicama hiperferitinemije s implikacijama na COVID-19.

KLJUČNE RIJEČI: hiperferitinemija; COVID-19; upala; metabolizam željeza; feritin 


\section{INTRODUCTION}

A new coronavirus identified in December 2019 in Wuhan caused a pandemic known as coronavirus disease-2019 (COVID-19), which is still ongoing. The vast efforts of the world scientific community have focused on studying both the new corona virus, i.e. severe acute respiratory syndrome coronavirus 2 (SARS-CoV-2) and the pathologies of the disease associated with this infection. The virus infects the respiratory organs, in severe cases the lung cells via the currently best-known receptor angiotensin-converting enzyme 2 (ACE2), although some other possibilities for the virus to enter the cell are mentioned ${ }^{1}$. Disease expression is associated with various risk factors eg. viral load, age, presence of comorbidities, innate and adaptive immune capabilities of the host, etc. ${ }^{2}$.

Common symptoms of the disease are different and include fever, dry cough, dyspnea, fatigue and myalgia, and less commonly headache, nausea, vomiting, rhinorrhea, loss of sense of smell and taste, depending on the stage of infection, age, comorbidities present, whereby not all must be involved at the same time ${ }^{3}$. The clinical picture of the disease is dominated by significant inflammation, respiratory problems, hypercoagulopathy, so the most common result of severe forms of the disease is the development of atypical form of acute distress respiratory syndrome (ARDS) with preserved lung gas volume ${ }^{4}$, with significant cytokine release, progressive hypoxia, impaired coagulation, and in severe cases multiorgan failure ${ }^{5}$.

COVID-19 is mostly expressed in asymptomatic or mild form (about $80 \%$ of cases) but also in more severe forms, which cause significant mortality and morbidity ${ }^{6}$. It is still not entirely clear why a smaller proportion of patients develop a very severe form and for now an excessive adaptive immune response and virusinduced pulmonary pathology are assumed ${ }^{7}$. Timely identification of individual disease phenotypes, reliable and specific indicators is therefore crucial for disease monitoring and for initiating targeted antiviral, anti-inflammatory, anticoagulant or even antifibrotic therapeutic approaches.

Primary respiratory problems, as well as other features of the disease, can, logically, based on already existing knowledge of respiratory pathophysiology, biochemistry and iron metabolism, be associated with potential disorders of iron homeostasis ${ }^{8,9}$. As a consequence of dysregulation of iron homeostasis, a decrease in the amount of functional hemoglobin with accompanying hypoxia, hypopheremia and thus hyperferritinemia can be mentioned ${ }^{10}$. Iron is crucial for the host as it participates in a number of physiological processes, nonenzymatyc and enzymatic reactions. The amount of iron is strictly regulated, as the potential presence of free iron can result in the formation of free radicals through Fenton and Haber-Weiss reactions, as well as damage of cells and organs. On the other hand, viruses also need iron because they need a host metabolic apparatus for their replication ${ }^{11}$. It has been described that some viruses can also alter the expression of proteins involved in iron homeostasis (e.g., hepcidin, hereditary hemochromatosis protein, etc. ${ }^{12}$. The significant role of changes in iron homeostasis in COVID-19 is supported by an increasing number of papers that include additional therapeutic approaches to these changes (eg. synthetic and naturaliron chelators, cellular iron depleting agents by regulating the expression of genes involved in iron metabolism, ferroptosis inhibitors, etc.) ${ }^{13,14}$.

Among other things, certain phases of COVID-19 development are characterized by significant changes in laboratory parameters. For now, laboratory tests can be singled out, some of which are important for distinguishing mild to severe forms of the disease, i.e. the assessment of the prognosis of the disease. These are, for example, changes in some hematological parameters (lymphopenia, neutrophilia, thrombocytopenia); coagulation parameters (D-dimers, prothrombin time (PT), activated partial thromboplastin time (APTT); indicators of systemic inflammation (ferritin, C-reactive protein (CRP), procalcitonin, neutrophil to lymphocyte ratio (NLR), cytokines); lactate dehydrogenase (LDH); bilirubin, etc. ${ }^{15}$.

The one of the most common and significant laboratory findings in patients with COVID-19 is hyperferritinemia, i.e. increased ferritin concentration in serum, one of the most important proteins for iron homeostasis. The purpose of this review is to collect literature data relating to the possible causes and consequences of hyperferritinemia in inflammation with currently possible implications for hypereferritinemia in COVID-19 patients. To this goal, databases (PubMed, WHO COVID-19 database, BioArx and MedArxiv preprint servers, Google Scholar, Embase, Web of Science, ScienceDirect) were reviewed. The search strategy was to use different search terms alone and in any combination, such as "COVID-19”, "SARS-CoV-2”, “iron”, „hepcidin“, „hemoglobin“, „ferritin“, hyperferritinemia“,virus infection“, "inflammation”, “immunity”, “cytokine”, “IL-6”, „tumor necrosis factor- $\alpha$, ("TNF- $\alpha$ ”, "IL-1 $\beta$.)” Only English articles with available data were included.

\section{BASIC CHARACTERISTICS OF FERRITIN}

Ferritin, primarily a cellular, non-glycosylated protein (Mr 450 $\mathrm{kDa}$ ), of all but especially cells of the reticuloendothelial system (RES; or synonym: monocyte-macrophage system - mononuclear-phagocyte system - MPS) and liver, is known as a molecule for storing iron ions, with a maximum capacity of $4500 \mathrm{Fe}^{3+}$ per molecule of ferritin ${ }^{16}$. In cells it can be localized in the cytoplasm, nucleus and mitochondria. Given the storage property of free, potentially toxic iron, this molecule is also considered a preventive antioxidant ${ }^{17}$. Depending on the body's continuous needs for iron, it serves as a dynamic "buffer" of iron, in maintaining the steady-state availability of iron. According to this role in iron metabolism, cellular ferritin values are regulated at the translational level by the iron regulatory proteins/iron respon- 
sive elements (IRP/IRE) regulatory system, which is dependent on the amount of iron in the body ${ }^{18}$. However, regulation by cytokines at the translational and transcriptional levels, especially in macrophages, has also been described, which could explain the increase in ferritin values in inflammatory conditions ${ }^{9,19,20}$. Human, cellular ferritin consists of 24 light (L) chain subunits responsible for the stability of the molecule and storage of iron in the apoferritin shell, and heavy chains $(\mathrm{H})$ responsible for the ferroxidase activity of ferritin. The result of this activity is the oxidation of $\mathrm{Fe}^{2+}$ to $\mathrm{Fe}^{3+}$ and thus the prevention of the potential formation of toxic hydroxyl radicals.

The $\mathrm{L}$ and $\mathrm{H}$ chains of ferritin are interchangeable and have different proportions in the ferritins of different tissues, which is presumably reflected in the function of this molecule ${ }^{21,22}$. Thus, in the ferritin of liver tissue and spleen, the L-subunit predominates (basic isoferritins classified according to $\mathrm{pI}$ ), while in the ferritin of the brain, kidneys and heart, the H-subunit predominates (acidic isoferritin classified according to $\mathrm{pI}$ ) ${ }^{17}$. The existence of ferritin in erythrocytes has also been proven, and it is also found in the systemic circulation, i.e. serum or plasma ${ }^{23,24,25}$. The entry of $\mathrm{Fe}^{2+}$ into the ferritin molecule is enabled by the existence of an electrostatic gradient that attracts metal cations, the corresponding channels and with the help of chaperone Poly$\mathrm{r}(\mathrm{C})$-Binding Protein-1 (PCBP1) ${ }^{26}$. This is usually followed by its oxidation to the $\mathrm{Fe}^{3+}$ storage form via the ferroxidase activity of the H-chain of ferritin and its placement in the cavity of the molecule. There are different ways of mobilizing iron from cellular ferritin depending on the condition, and among others, a significant place in vivo is attributed to the decomposition of ferritin, the process of ferritinophagy (a subtype of autophagy). Serum ferritin contains less iron per molecule ${ }^{27}$, is largely composed of L-subunits in contrast to cellular ferritin. In contrast to the clinical potential of serum ferritin, the function or possible effects of serum ferritin are largely unknown at present. This form of ferritin is often posttranslational glycosylated (60$80 \%)^{28}$, since the L-subunit contains a site for N-glycosylation ${ }^{29}$ and is thought to be of hepatic origin ${ }^{17,29}$. Carbohydrate residues are acquired during the process of secretion from tissues into the systemic circulation, and the process is mediated by RES cells and hepatocytes ${ }^{29}$. The degree of glycosylation can also affect the rate of removal of ferritin from plasma, so, as described, the half-life of glycosylated ferritin is significantly longer (50 hours) compared to non-glycosylated ( 5 hours) ${ }^{30}$. Furthermore, the proportions of glycosylated and non-glycosylated ferritin in serum appear to change during some diseases so that the proportion of glycosylated ferritin decreases to a level of $20 \%{ }^{31}$. In this sense, the saturation of known glycosylation mechanisms ${ }^{32}$ but also cell damage and lysis, which is shown on liver cells ${ }^{33}$, is considered as the cause of the decrease. Therefore, it is hypothesized that the degree of glycosylation of serum ferritin could help to differentiate the underlying pathology of various diseases, more specifically the differential diagnosis of hyperferritinemia ${ }^{34,35}$. These assumptions would be desirable to confirm and examine multiple times in patients with COVID-19.

The origin of serum ferritin is still debated and is mentioned on the one hand by simple release from damaged cells and on the other by active secretion from cells via non-classical vesicular pathways and multivesicular body- exosome pathway ${ }^{21,36,37}$. As the concentrations of ferritin in the cell are about 1000 times higher than those in the serum, Kell et al. present arguments to support the view that the occurrence of serum ferritin is the result of cellular stress and cell lysis („hyperferritinemia of cytolysis") ${ }^{21,38}$. In addition, they state that serum ferritin values correlate with markers of a) liver cell damage, b) markers of hydroxyl radical formation and oxidative stress, c) erythrocyte microparticles values and d) with the presence and/or severity of a number of diseases (e.g., ARDS, amyotrophic lateral sclerosis, atherosclerosis, cancer, cirrhosis of the liver, coronary artery disease, diabetes mellitus type 2, etc.).

Active ferritin secretion is supported by some studies in mice, primary macrophage cultures, as well as on splenectomy in animals that resulted in a decrease in serum ferritin, also as evidence of macrophage contribution to serum ferritin values ${ }^{36,39}$.

Furthermore, the release of iron-loaded ferritin into the systemic circulation is mentioned, as a consequence of the inhibition of ferroportin (the only known exporter of iron from cells), due to the increased expression of hepcidin in conditions of severe inflammation ${ }^{40}$. The mode of such release is unclear but putative mechanisms include, for example, exocytosis, secretion by secretory lysosomes, and transcytosis ${ }^{19,29,36}$. The biological significance of both the secretion and the utilization of the ferritin molecule in the systemic circulation is currently unknown. It is assumed that ferritin acts as an iron donor, i.e. it is introduced into e.g. erythroid precursors for hemoglobin synthesis ${ }^{41}$.

Determination of serum ferritin concentration is used primarily to assess the body's iron supply. Serum ferritin is also known as a marker of inflammation, although its role in the inflammatory process is not yet clear ${ }^{21}$. This reduces the diagnostic value of determining ferritin as an indicator of body iron status and a more accurate marker is considered to be the determination of the soluble transferrin receptor (sTfR): $\log$ ratio of ferritin ("sTfR index") ${ }^{42}$.

\section{HYPEREFERRITINEMIA WITH IMPLICATIONS FOR CO- VID-19}

In addition to inflammation often called "cytokine storm", a striking laboratory feature in COVID-19 is the increased serum ferritin concentration. Retrospective studies from several centers in Wuhan found that, for example, ferritin concentrations at admission were between 1.5 and 5.3 times higher in patients with more severe, compared to milder forms of the disease and 3-4 times higher in non-survivors compared to surviving patients ${ }^{43}$. 
Kappert K. et al. have tried in a review paper to find data and compare ferritin values in patients with COVID-19, with values in several other infectious diseases. For SARS-CoV, Middle East respiratory syndrome (MERS) and $\mathrm{H} 1 \mathrm{~N} 1$, such data were not even found; for influenza $A$, one paper described, for example, mean ferritin values of about $600 \mu \mathrm{g} / \mathrm{L}$ for patients with a poor outcome, compared to others with a value of about $217 \mu \mathrm{g} / \mathrm{L}$. There are a number of studies involving ferritin values in COVID-19 patients that could be summarized as follows: in mild and moderate forms of the disease (as well as in surviving patients and patients without ARDS), serum ferritin values were generally $<1000 \mu \mathrm{g} / \mathrm{L}$, while in severe, extremely severe (non-survivors and non-survivors with ARDS) were $>1000 \mu \mathrm{g} / \mathrm{L}$. The final conclusion was that there was a correlation of serum ferritin values with disease severity and poor final outcome for the patient ${ }^{44}$. The organism, i.e. the cells, therefore react to the stress-inflammatory state and produce large amounts of ferritin, and whether ferritin is only a sign of disease progression or has a modulating role in the pathogenesis of the disease is still debated ${ }^{43,45}$. Increased serum ferritin levels in the inflammatory state support the immune system, limiting the availability of iron to pathogens ${ }^{46,47}$. The final result of such changes, as described, is a decrease in the concentration of iron in the systemic circulation, and as a reflection of the increase in ferritin in cells, an increase in serum ferritin, which was also recorded in COVID-19 ${ }^{48,49}$. Such changes are usually a feature of changes in iron metabolism in the inflammatory state. Such laboratory findings are common in inflammation, reflecting increased concentrations of hepcidin, the major iron regulator, and indirectly ferritin. Additionally, in the literature, based on the similarity of part of the spike glycoprotein structure of SARS-CoV-2 virus and hepcidin, it is hypothesized that this protein could have a hepcidin-like effect ${ }^{10}$. This would mean that this viral protein may further increase cellular and serum concentrations ferritin regardless of the inflammatory effect, which should certainly be supported by further experimental research.

Reports of decreased ferritin and IL-6 levels in accordance with the recovery of patients with COVID- $19^{50}$ on the one hand confirmed the association of hyperferritinemia with inflammation and indicated a potential role as a parameter indicating disease severity and cytokine storm extent. On the other hand, they also stimulated considerations about the possible role of ferritin as a participant in the inflammatory process itself ${ }^{51}$, considering both the immunosuppressive ${ }^{52,53,54}$ and pro-inflammatory properties of ferritin ${ }^{55}$.

There are reports of complex feedback mechanisms between ferritin and cytokines in the control of pro-inflammatory and anti-inflammatory mediators. The process of ferritin synthesis is stimulated by cytokines at both the transcriptional and translational levels in a variety of cells, including macrophages ${ }^{51,56}$. Cytokines, including IL-6, IL- $1 \beta$, and TNF- $\alpha$ can stimulate the expression and subsequent secretion of ferritin from, for example macrophages. The macrophages that make up most of the immune cells in the lung parenchyma are the main "pool" of iron as they phagocytose obsolete erythrocytes ${ }^{52,57}$. It has been described that the expression of relative ratios of ferritin subunits is affected by inflammation, i.e. that cytokines and paracrine signaling molecules such as nitrogen monoxide, increase the relative content of the H-subunit and directly affect the IRP/IRE control system ${ }^{58}$. In addition to modulating expression via mentioned system, there is also modulation in an IRP/IRE-independent manner, as shown in vitro on fibroblasts treated with TNF- $\alpha$ and IL- $1 \alpha$ with an increase in the H-subunit of ferritin ${ }^{59}$. According to current knowledge, the expression of the $\mathrm{H}$-subunit of ferritin is most often increased by inflammatory stimuli.

It has been shown that ferritin as a signaling molecule can induce the expression of pro-(e.g. IL-1 $\beta$ ) and anti-inflammatory cytokines (e.g. IL-10) ${ }^{43,54}$. The immunomodulatory properties of ferritin are attributed to the increased expression of the $\mathrm{H}$ subunit of ferritin ${ }^{9,17}$. According to Shoenfeld et al., the H-chain of ferritin could be important in macrophage activation in terms of increased secretion of inflammatory cytokines and in COVID-19 ${ }^{60}$ whose clinical picture resembles macrophage activation syndrome. Based on some experimental research on activated rat hepatic stellate cells, the possibility of a direct causal role of ferritin in the inflammatory process, i.e. the action of ferritin as a local cytokine ${ }^{61}$, cannot be ruled out, which should certainly be examined in the case of COVID-19.

Based on in vitro studies, it has been shown that $\mathrm{T}$ and $\mathrm{B}$ lymphocytes and other cell types bind directly to the H-subunit of ferritin during inflammation, by a hitherto unknown mechanism $^{52,62}$, although various potential receptors are also listed. The result is an immunosuppressive effect, more specifically a reduction in T-cell proliferation, B-cell maturation, and immunoglobulin production ${ }^{61,62,63}$.

Significant hyperferritinemia accompanied by inflammation with a cytokine storm, called hyperferritinemic syndrome" (includes: Macrophage activation syndrome (MAS), Adult-onset Still's disease (AOSD), Catastrophic antiphospholipid syndrome (CAPS), and Septic shock) is also characterized by COVID 19, so this disease currently considered as the fifth member within the definition of hyperferritinemic syndrome ${ }^{64}$. Common features of this syndrome and COVID-19 in addition to hyperferritinemia are: lymphopenia, decreased number and activity of natural killer $(\mathrm{NK})$ cells, abnormal liver function tests and coagulopathy ${ }^{54}$. Some authors associate certain morphological changes of erythrocytes such as deformability and shorter half-life with an increase in free, potentially toxic iron values derived from ferritin released from damaged cells ${ }^{21,65}$. It is also mentioned in the literature that the change of fibrin from the usual mesh layer to a turbid mass which can result in the formation of a rigid clot resistant to fibrinolysis ${ }^{21,66}$ and contribute to vascular problems 


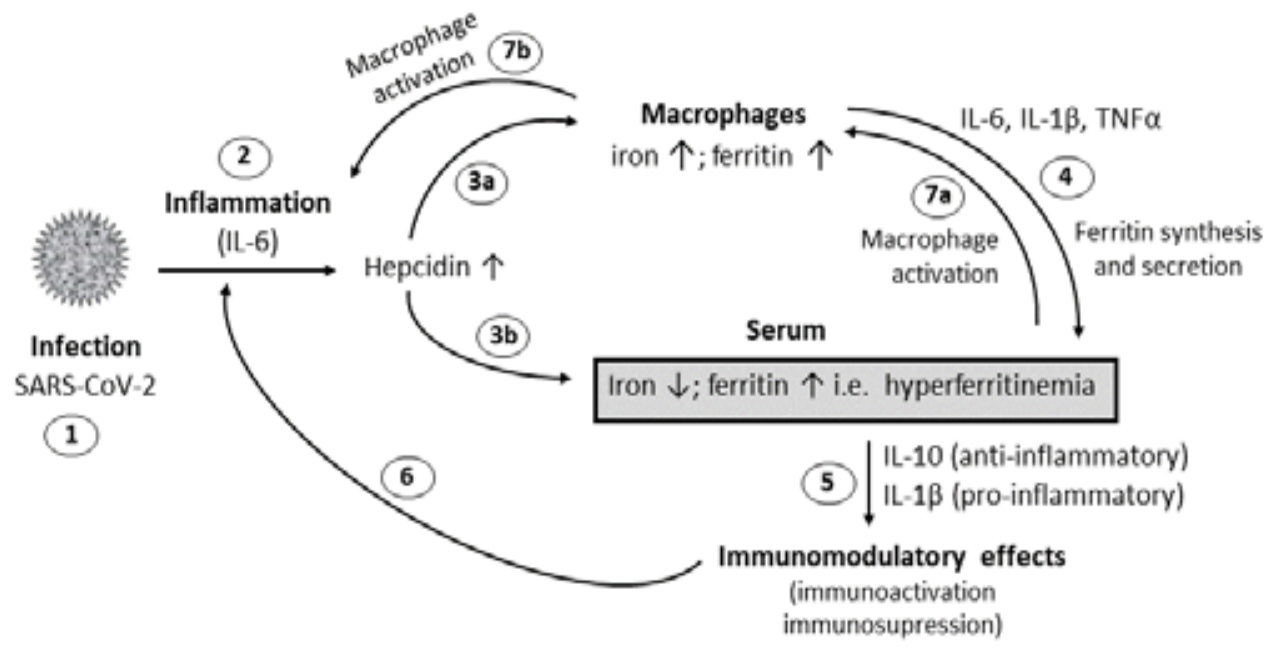

Figure 1. Potential role of hyperferritinemia during inflammation in COVID-19.

(1) Infection with SARS-CoV-2; (2) Activation of hepcidin expression by IL-6; (3a) The result of the increase in hepcidin is the enhanced storage of iron within ferritin in macrophages; (3b) The result of the increase in hepcidins the decreased serum iron as well as increased ferritin values, i.e. hyperferritinemia; (4) Enhanced synthesis and secretion of ferritin from macrophages due to cytokine action; (5) Immunomodulatory effect of hyperferritinemia; (6) Further stimulating inflammation by the immunoactivation effects of ferritin; (7a) and (7b). Further consequences of macrophage activation. (SARS-Cov-2) severe acute respiratory syndrome coronavirus-2; (IL) interleukine; (TNF $\alpha$ ) tumor necrosis factor $\alpha$; ( $\uparrow$ increased value; ( $\downarrow$ ) decreased value.

in various diseases. Pharmacological (eg. deferoxamine) or nutritional (polyphenolic antioxidants) iron chelators are therefore recommended as adjunctive therapy to counteract the effects of released iron ${ }^{67}$.

Hyperferritinemia, with consequent ferritinophagia, is also crucial for the induction of a specific, relatively new form of regulated cell death of ferroptosis ${ }^{68}$. Ferroptosis is an inherently more immunogenic form of death than for example, apoptosis, because the affected cells release inflammatory cytokines and damage-associated molecular patterns (DAMPs), which contribute to the proinflammatory state ${ }^{69,70}$. In addition to DAMPs, some ferroptotic cells can release high mobility group-1 (HMGB1) in a manner associated with autophagy, a molecule that is also involved in the pathogenesis of inflammation ${ }^{71}$. The association of ferritinophagy and ferroptosis has been described and ferritinophagy is thought to be one of the key events in ferroptosis ${ }^{72,73}$. The process of ferritinophagy involves the cargo receptor nuclear receptor coactivator-4 (NCOA4) which binds to ferritin, more precisely to the $\mathrm{H}$-subunit of ferritin, transmits it from the cytosol to the lysosomes ${ }^{74}$. The result is the release of free iron and the consequent formation of lysosomal reactive oxygen species ${ }^{75}$. It can therefore be concluded that changes in ferritin expression affect ferroptosis by altering the intracellular pool of free and redox active iron ${ }^{76}$.

Ferroptosis is a type of iron-dependent cell death that also causes an irreversible change in the morphology of mitochondria ${ }^{77}$, organelles necessary to provide the energy needed for cellular functions in accordance with bodily needs. Mitochondrial homeostasis disorders are therefore involved in the pathogenesis of various diseases ${ }^{78}$. Hyperferritinemia can affect mitochondrial homeostasis and thereby redirect mitochondria from the aerobic to the anaerobic state. Such changes would be consistent with the increased LDH values observed in patients with COVID-19 ${ }^{5,79}$. According to Hirschhorn T. et al. hyperferritinemia leads to severe oxidative stress, lipoperoxidation, and mitochondrial-level ferroptosis, and increases mitophagy with accelerated cell death ${ }^{80}$. The question can be asked whether, for example, hyperferritinemia and insufficient mitochondrial capacity of iron metabolism in COVID-19 cause ferroptosis of the bronchial epithelium, but also other cells? Opinions differ on the significance of hyperferritinemia. From being an "innocent passer-by", a biological marker of uncontrolled inflammation, to ferritin having a protective role, to being a key mediator of immune dysregulation in conditions of extreme hyperferritinemia, through immunosuppressive and pro-inflammatory effects ${ }^{9,81}$. Hyperferritinemia is also potentially associated with an increase in free redox active iron, which can further cause a number of direct and indirect organ disorders during COVID-19. It is possible that in COVID-19 there may be a vicious cycle of inflammation, associated with dysfunction of iron homeostasis and increased serum ferritin levels, which may lead to tissue damage (Figure 1.).

\section{CONCLUDING REMARKS}

The knowledge about the SARS-CoV-2 and its associated disease is continuously successfully collected but still keeps the world in suspense. Given the relatively high proportion of hospitalized patients but also deaths, it is necessary to define and validate new existing clinically relevant and reliable diagnostic and prognos- 
tic clinical and laboratory markers of COVID-19. This would increase the understanding of the pathogenesis of the disease and facilitate a proper therapeutic approach.

Numerous reports to date have shown increased serum ferritin to have clinical and discriminatory potential to define the severity of COVID-19. Due to the similarity of several laboratory features, this disease is increasingly mentioned as a possible fifth member of the so-called "hyperferritinemiy syndrome". However, ferritin is not a specific laboratory marker, as increased concentrations have been reported in other inflammatory conditions of infectious and non-infectious origin.

As hyperferritinemia appears to identify COVID-19 patients at high risk of mortality, and its reduction indicates improved survival, there is a need for further investigation the structure and role of ferritin in inflammatory conditions on the one hand as a biomarker, but on the other hand as a mediator of COVID-19. In order to increase the diagnostic specificity of increased serum ferritin values in predicting disease progression and association with the inflammatory process, further targeted and well-planned multicenter studies on a larger number of samples need to be done. Accordingly, it is necessary to determine ferritin values in better defined groups of patients, including asymptomatic infected persons, persons in the very early stages of the disease, nonhospitalized patients with mild COVID-19, subjects of different age groups. It should be also monitored ferritin values during the disease to establish the value of this analyte in terms of monitoring current and future therapeutic approaches as well as the effects of developing vaccines; setting limit values on the basis of which patients could be classified into groups in terms of an appropriate therapeutic approach; defining critical ferritin values. In order to assess the contribution of possible hypopheremia to concomitant hyperferritinaemia, in a condition such as severe inflammation and its association with hypoxia associated with poor outcomes in COVID-19, determine the values of other coexisting participants in iron metabolism (eg. iron concentration, hemoglobin, hepcidin transferin saturation). In other words, it is important to establish the reliability of determining serum ferritin concentration in reflecting the severity of COVID-19 and its monitoring. The mechanisms by which hyperferritinemia contributes to the pathogenesis of COVID-19 are currently unclear. We hope, therefore, that in this sense, this brief review will encourage further research, inter alia in the direction of: defining the immunomodulatory properties of ferritin by comparatively determining the values of pro-inflammatory and anti-inflammatory cytokines; based on the definition of the ratio of $\mathrm{L}$ and $\mathrm{H}$-chains to determine the origin of serum ferritin; determination of iron in serum ferritin; assess whether and to what extent macrophage activation contributes to hyperferritinemia in COVID-19 by determining the degree of serum glycosylation of ferritin, value of sCD163 and circulating microparticles (cMPs), also indicators the monocyte-macrophage activity; examining whether hyperferritinemia may be a target for therapeutic intervention; and, for example, testing the sensitivity of iron-enriched tissue macrophages to SARS-CoV-2 and its ability to generate de novo infectious viral particles.

As in most systematic reviews, this one has some limitations that of course require further discussion and confirmation. COVID-19 is a new disease and although the focus of scientific research has been limited due to lack of reliable information some published papers are theoretical in nature, some papers provide only partial information, some papers have not passed peer review, in some cases conclusions are based on limited amounts of data and should be confirmed by additional research.

\section{LITERATURE:}

1. Ulrich H, Pillat MM. CD147 as a target for COVID-19 treatment: suggested effects of azithromycin and stem cell engagement. Stem Cell Rev Rep. 2020;20: 1-7.

2. Dodig D, Čepelak I, Čepelak Dodig D, Laškaj R. SARS-

CoV-2 - a new challenge for laboratory medicine. Biochem Med. 2020;30:030503.

3. Zhu J, Zhong Z, Ji P, Li H, Li B, Pang J, et al. Clinicopathological characteristics of 8697 patients with COVID-19 in China: a meta-analysis. Fam Med Community Health. 2020;2020;8:e000406. 4. Gattinoni L, Coppola S, Cressoni M, Busana M, Rossi S, Chiumello D. Covid-19 does not lead to a "typical" acute respiratory distress syndrome. Am J Respir Crit Care Med. 2020;201:1299-1300. 5. Huang C, Wang Y, Li X, Ren L, Zhao J, Hu Y, et al. Clinical features of patients infected with 2019 novel coronavirus in Wuhan, China. Lancet. 2020;395:P497-506.
6. Yuki K, Fujiogi M, Koutsogiannaki S. COVID-19 pathophysiology: a review. Clin Immuno. 2020;215:108427.

7. Guan W, Ni Z, Hu Y, Liang W, Ou C, He J, et al. Clinical characteristics of coronavirus disease 2019 in China. N Engl J Med. 2020;382:1708-1720.

8. Mehta P, McAuley DF, Brown M,Sanchez E, Stattersall R, Manson JJ. COVID-19: consider cytokine storm syndromes and immunosuppression. Lancet 2020;395:1033-4.

9. Kernan KF, Carcillo JA. Hyperferritinemia and inflammation. Int Immunol. 2017:29:401-9.

10. Cavezzi A, Troiani E, Corrao S. COVID-19: hemoglobin, iron, and hypoxia beyond inflammation. A narrative review. Clin Pract. 2020;10:1271.

11. Drakesmith H, Prentice A. Viral infection and iron metabolism. Nat Rev Microbiol. 2008;6:541-52.

12. Schmidt SM. The role of iron in viral infections. Front Biosci

(Landmark Ed.). 2020;25:893-911. 
13. Hadadi A, Mortezazadeh M, Kolahdouzan K, Alavian G. Does recombinant human erythropoietin administration in critically ill COVID-19 patients have miraculous therapeutic effects? J Med Virol. 2020;92:915-8.

14. Kumari N, Ammosova T, Diaz S, Lin X, Niu X, Ivanov A, et al. Increased iron export by ferroportin induces restriction of HIV-1 infection in sickle cell disease. Blood Adv. 2016;1:170-83.

15. Frater JL, Zini G, d'Onofrio G, Rogers HJ. COVID-19 and the clinical hematology laboratory. Int J Lab Hematol. 2020;42:Suppl:1. 16. Liu X, Theil EC. Ferritins: dynamic management of biological iron and oxygen chemistry. Acc Chem Res. 2005;38:167-75.

17. Arosio, P, Ingrassia R, Cavadini P. Ferritins: A family of molecules for iron storage, antioxidation and more. Biochim Biophys Acta Gen Subj. 2009;1790:589-99.

18. Kuhn LC. Iron regulatory proteins and their role in controlling iron metabolism. Metallomics. 2015;7:232-43.

19. Tran TN, Eubanks SK, Schaffer KJ, Zhou CY, Linder MC. Secretion of ferritin by rat hepatoma cells and its regulation by inflammatory cytokines and iron. Blood. 1997;90:4979-86.

20. Fahmy M,Young SP. Modulation of iron metabolism in monocyte cell line U937 by inflammatory cytokines: changes in transferrin uptake, iron handling and ferritin mRNA. Biochem J. 1993;296 (Pt 1):175-81. 21. Kell B, Pretorius E. Serum ferritin is an important inflammatory disease marker, as it is mainly a leakage product from damaged cells. Metallomics. 2014;6:748-73.

22. Theil EC. Ferritin protein nanocages use ion channels, catalytic sites, and nucleation channels to manage iron/ oxygen chemistry. Curr Opin Chem Biol. 2011;15:304-11.

23. Alkhateeb AA, Connor JR. Nuclear ferritin: a new role for ferritin in cell biology. Biochim Biophys Acta. 2010;1800:793-7.

24. Arosio P, Levi S. Cytosolic and mitochondrial ferritins in the regulation of cellular iron homeostasis and oxidative damage. Biochim Biophys Acta. 2010;1800:783-92.

25. Novembrino C, Porcella A, Conte D, de Vecchi AF, Buccianti G, Lonati $S$, et al. Erythrocyte ferritin concentration: analytical performance of the immunoenzymatic IMx-Ferritin (Abbott) assay, Clin Chem Lab Med. 2005;43:449-53.

26. Shi H, Bencze KZ, Stemmler TL, Philpott CC. A cytosolic iron chaperone that delivers iron to ferritin. Science. 2008;320:1207-10. 27. Ren Y, Walczyk T. Quantification of ferritin bound iron in human serum using speciesspecific isotope dilution mass spectrometry. Metallomics. 2014;6:1709-17.

28. Cragg SJ, Wagstaff M,Worwood M. Detection of a glycosylated subunit in human serum ferritin. Biochem J. 1981;199:565-71.

29. Ghosh S, Hevi S, Chuck SL. Regulated secretion of glycosylated human ferritin from hepatocytes. Blood. 2004;103:2369-76. 30. Worwood M, Cragg SJ, Williams AM, Wagstaff M, Jacobs A. The clearence of 131 I-human plasma ferritin in man. Blood. 1982;60:827-33.

31. Fautrel B, Moël G, Saint-Marcoux B, Taupin P, Vignes S, Rozenberg $S$, et al. Diagnostic value of and glycosylated ferritin in adult onset Still's disease. J Rheumatol. 2001;28:322-9.
32. Fautrel B. Adult-onset Still disease. Best Pract Res Clin Rheumatol. 2008;22:773-92.

33. Worwood M, Cragg SJ, Wagstaff M, Jacobs A. Binding of human serum ferritin to concanavalin A. Clin Sci (Lond.). 1979;56:83-7. 34. Lambotte O, Cacoub P, Costedoat N, Le Moel G, Amoura Z, Piette JC. High ferritin and low glycosylated ferritin may also be a marker of excessive macrophage activation. J Rheumatol. 2003;30:1027-28.

35. Gasser BI. Determination of serum ferritin glycosilation in hyperferritinemia associated to iron overload and inflammation. EJIFCC. 2009;20:136-40.

36. Cohen LA, Gutierrez L, Weiss A, Leichtmann-Bardoogo Y, Zhang DL, Crooks DR, et al. Serum ferritin is derived primarily from macrophages through a nonclassical secretory pathway. Blood. 2010;116:1574-84.

37. Truman-Rosentsvit M, Berenbaum D, Spektor L, Cohen LA, Belizowsky-Moshe S, Lifshitz L, et al. Ferritin is secreted via 2 distinct nonclassical vesicular pathways. Blood 2018;131:342-52.

38. Serraj K, Hamaz S, Alaloui H, Bachir H, Andrès E. Diagnosis of hyperferritinemia in 2019. Integr Food Nutr Metab. 2019;6:1-4. 39. Colafrancesco S, Priori R, Alessandri C, Astorri E, Perricone C, Blank M, et al. sCD163 in AOSD: a biomarker for macrophage activation related to hyperferritinemia. Immunol Res. 2014;60:177-83. 40. Nemeth E, Valore EV, Territo M, Schiller G, Lichtenstein A, Ganz T. Hepcidin, a putative mediator of anemia of inflammation, is a type II acute-phase protein. Blood. 2003;101:2461-63.

41. Gelvan D, Fibach E, Meyron-Holtz EG, Konijn AM. Ferritin uptake by human erythroid precursors is a regulated iron uptake pathway. Blood. 1996;88:3200-7.

42. Skikne S, Punnonen K, Caldron PH, BennettMT, Rehu M, Gasior GH, et al. Improved differential diagnosis of anemia of chronic disease and iron deficiency anemia: A prospective multicenter evaluation of soluble transferrin receptor and the $s \mathrm{TfR} / \mathrm{log}$ ferritin index. Am J Hematol. 2011;86:923-7.

43. Gómez-Pastoraa J, Weiganda M, Kima J, Wua X, Strayera J, Palmera AF, et al. Hyperferritinemia in critically ill COVID-19 patients - Is ferritin the product of inflammation or a pathogenic mediator? Clin Chim Acta. 2020;509:249-51.

44. Kappert K, Jahić A, Tauber R. Assessment of serum ferritin as a biomarker in COVID-19: bystander or participant? Insights by comparison with other infectious and noninfectious diseases. Biomarkers. 2020;1-36. 45. Edeas M, Saleh J, Peyssonnaux C. Iron: Innocent bystander or vicious culprit in COVID-19 pathogenesis? Int J Infect Dis. 2020;97:303-5.

46. Pieracci FM, Barie PS. 2005. Iron and the risk of infection. Surg Infect (Larchmt). 2005;6:Suppl:1.

47. Parrow NL, Fleming RE, Minnick MF. Sequestration and scavenging of iron in infection. Infect Immun. 2013;81:3503-14.

48. Zhao K, Huang J, Dai D, Feng Y, Liu L, Nie S. Serum iron level as a potential predictor of coronavirus disease 2019 severity and mortality: A Retrospective Study. Open Forum Infect Dis. 2020;21:ofaa250. 
49. Alipour R, Hashemi SH, Mikaeili F. Serum iron level in patients with COVID-19: a case report study. Int J Res Med Sci. 2020;8:2658-62.

50. Liu T, Zhang J, Yang Y, Ma H, Li Z, Zhang J, et al. The potential role of IL-6 in monitoring severe case of coronavirus disease 2019. EMBO Mol Med. 2020;12:e12421.

51. Recalcati S, Invernizzi P,Arosio P, Cairo G. New functions for an iron storage protein: The role of ferritin in immunity and autoimmunity. J Autoimmun. 2008;30:84-9.

52. Ruscitti P, Cipriani P, Benedetto PD, Liakouli V, Berardicurti $\mathrm{O}$, Carubbi F, et al. $\mathrm{H}$-ferritin and proinflammatory cytokines are increased in the bone marrow of patients affected by macrophage activation syndrome. Clin Exp Immunol. 2018;191:220-28.

53. Zarjou A, Black LM, McCullough KR, Hull TD, Esman SK, Bod$\mathrm{du} \mathrm{R}$, et al. Ferritin light chain confers protection against sepsis-induced inflammation and organ injury. Front Immunol. 2019;10:131. 54. Rosario C, Zandman-Goddard G, Meyron-Holtz EG, D’Cruz DP and Shoenfeld Y. The hyperferritinemic syndrome: macrophage activation syndrome, Still's disease, septic shock and catastrophic antiphospholipid syndrome. BMC Med. 2013;11:185.

55. Ruddell RG, Hoang-Le D, Barwood JM, Rutherford PS, Piva TJ, Watters DJ, et al. Ferritin functions as a proinflammatory cytokine via iron-independent protein kinase $\mathrm{C}$ zeta/nuclear factor kappaB-regulated signaling in rat hepatic stellate cells. Hepatology. 2009;49:887-900. 56. Leimberg MJ, Prus E, Konijn AM, Fibach, E. Macrophages function as a ferritin iron source for cultured human erythroid precursors. J Cell Biochem. 2008;103:1211-8.

57. Delaby C, Pilard N, Hetet, Driss F, Grandchamp B, Beaumont C, et al. A physiological model to study iron recycling in macrophages. Exp Cell Res. 2005;310:43-53.

58. Harrison PM, Arosio P. The ferritins: molecular properties, iron storage function and cellular regulation. Biochim Biophys Acta. 1996;1275:161-203.

59. Kwak EL, Larochelle DA, Beaumont C, Torti SV, Torti FM. Role for NF-kappa B in the regulation of ferritin $\mathrm{H}$ by tumor necrosis factor-alpha. J Biol Chem. 1995;270:15285-93.

60. Shoenfeld Y. Corona (COVID-19) time musings: Our involvement in COVID-19 pathogenesis, diagnosis, treatment and vaccine planning. Autoimmun Rev. 2020;19:102538.

61. Fargion S, Fracanzani AL, Brando B, Arosio P, Levi S, Fiorelli G. Specific binding sites for $\mathrm{H}$-ferritin on human lymphocytes: modulation during cellular proliferation and potential implication in cell growth control. Blood. 1991;78:1056-61.

62. Yamashita M, Harada G, Matsumoto SE, Aiba Y, Ichikawa A, Fujiki T, et al. Suppression of immunoglobulin production in human peripheral blood mononuclear cells by monocytes via secretion of heavy-chain ferritin. Immunobiology. 2014;219:149-57.

63. Li R, Luo C, Mines M, Zhang J, Fan GH. Chemokine CXCL12 induces binding of ferritin heavy chain to the chemokine receptor CXCR4, alters CXCR4 signaling, and induces phosphorylation and nuclear translocation of ferritin heavy chain. J Biol Chem. 2006;281:37616-27.
64. Colafrancesco S, Alessandri C, Conti F, Priori R. COVID-19 gone bad: A new character in the spectrum of the hyperferritinemic syndrome? Autoimm Rev. 2020;19:102573.

65. Reggiori G, Occhipinti G, De Gasperi A, Vincent JL, Piagnerelli

M. Early alterations of red blood cell rheology in critically ill patients. Crit Care Med. 2009;37:3041-6.

66. Lipinski B, Pretorius E, Oberholzer HM, van der Spuy WJ. Interaction of fibrin with red blood cells: the role of iron. Ultrastruct Pathol. 2012;36:79-84.

67. Chang TP, Rangan C. Iron poisoning: a literature based review of epidemiology, diagnosis, and management. Pediatr Emerg Care. 2011;27:978-85.

68. Tang M, Chen Z, Wu D, Chen L. Ferritinophagy/ferroptosis: iron-related newcomers in human diseases. J Cell Physiol. 2018;233:9179-90.

69.Sun Y, Chen P, Zhai P, Zhang M, Xiang Y, Fang J, et al. The emerging role of ferroptosis in inflammation. Biomed Pharmacother. 2020;127:110108.

70. Čepelak I, Dodig S, Čepelak- Dodig D. Ferroptosis: regulated cell death. Arh Hig Rada Toksikol. 2020;71:99-109.

71. Son GH, Kim Y, Lee JJ, Lee KY, Ham H, Song JE, et al. MicroRNA-548 regulates high mobility group box 1 expression in patients with preterm birth and chorioamnionitis. Sci Rep. 2019;9:19746.

72. Capelletti MM, Manceau H, Puy H, Peoc'h K. Ferroptosis in liver diseases: An Overview. Int J Mol Sci. 2020;21:4908.

73. Hou W, Xie Y, Song X, Sun X, Lotze MT, Zeh HJ, et al. Autophagy promotes ferroptosis by degradation of ferritin. Autophagy. 2016;12:1425-8.

74. Latunde-Dada GO. Ferroptosis: role of lipid peroxidation, iron and ferritinophagy. BBA-Gen Subj. 2017;1861:1893-900.

75. Santana-Codina N, Mancias JD. The role of NCOA4-mediated ferritinophagy in health and disease. Pharmaceuticals (Basel). 2018;11:114.

76. Torii S, Shintoku R, Kubota C, Yaegashi M, Torii R, Sasaki M, et al. An essential role for functional lysosomes in ferroptosis of cancer cells. Biochem J. 2016;473:769-77.

77. Twig G, Shirihai OS. The interplay between mitochondrial dynamics and mitophagy. Antioxidants Redox Signal. 2011;14:1939-51.

78. Melser S, Lavie J, Bénard G. Mitochondrial degradation and energy metabolism. Biochim Biophys Acta. 2015;1853:2812-21.

79. Young A, Oldford C, Mailloux RJ. Lactate dehydrogenase supports lactate oxidation in mitochondria isolated from different mouse tissues. Redox Biol. 2020;28:1-7.

80. Hirschhorn T, Stockwell BR. The development of the concept of ferroptosis. Free Radic Biol Med. 2019;133:130-43.

81. Abbaspour N, Hurrell R, Kelishadi R. Review on iron and its importance for human health. J Res Med Sci. 2014;19:164-74. 